\title{
Native Script in MathSciNet: Celebrating Diversity
}

\author{
by Allyn Jackson
}

Mathematics has forever been an international subject, carried out by people all over the planet. Today the professional output of the field is dominated not only by the English language but also by the Roman alphabet. There are many legitimate reasons for this dominance, but it does tend to mask the diversity of the people who do mathematics. One small way of revealing and celebrating this diversity is being carried out through the "native script" capability in MathSciNet ${ }^{\circledR}$.

Each of the approximately 857,000 authors in MathSciNet has an individual author page that presents data about the person: full name, names of co-authors, number of publications, areas of those publications, and other information. Authors can personalize their pages by, for example, adding a photo of themselves or a link to a personal website.

In addition, those whose names are properly written using characters or an alphabet other than Roman can now have their names appear on their MathSciNet author page in native script. For example, on the author page for Japanese Fields Medalist Shigefumi Mori, one also sees his name as 森重文. For some deceased mathematicians, Math Reviews staff have added names in native script, so that, for example, the Russian mathematician Andrei Nikolaevich Kolmogorov also appears as Андрей Николаевич Колмогоров.

In some cases, names that differ in native script end up identical when transliterated into Roman letters. The native script capability helps to avoid such ambiguity and to allow clearer identification of authors.

The availability of native script in MathSciNet was made possible by a donation from $\mathrm{T}_{\mathrm{E}} \mathrm{X}$ creator Donald Knuth (see sidebar on Knuth, page 61), who has an abiding love for

Allyn Jackson, a freelance writer and editor, was formerly senior writer and deputy editor of the Notices. Her email address is a 11ynjacksn@gmai1.com.

For permission to reprint this article, please contact: reprint-permission@ams.org.

DOI: http://dx.doi.org/10.1090/noti1626

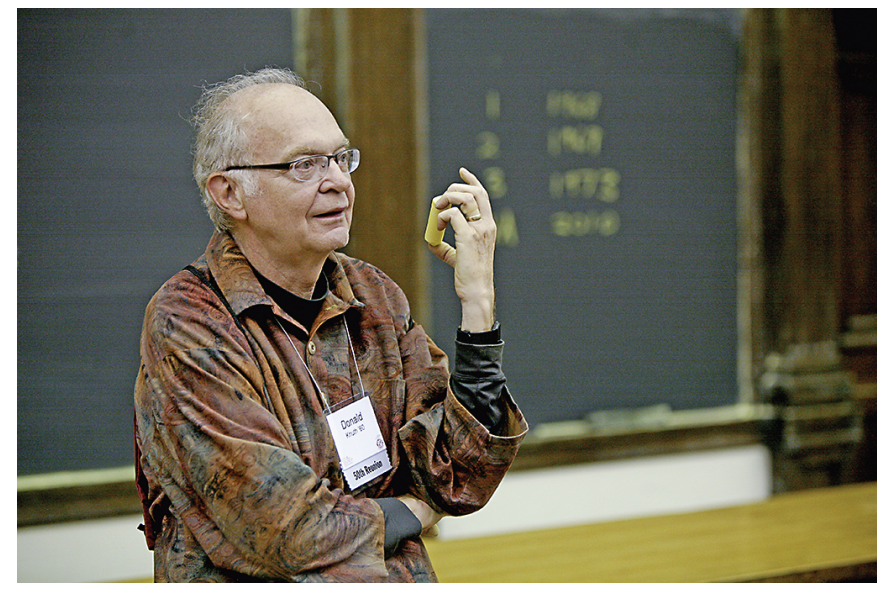

$T_{E} X$ creator Donald Knuth's donation made possible native script in MathSciNet author pages. Here he is lecturing at Case Western Reserve University in May 2010.

all things typographical-as well as a deep appreciation of diversity. "I view mathematics and computer science as a collaboration between thousands and thousands of people from many different cultures," he said. "Many historians present mathematics as consisting of a few great people who reached some milestones. I think of it more like the Great Wall of China-it's made out of a million individual bricks, each of which were important stones."

Knuth has long paid meticulous attention to how people's names are written. In 1967, when he prepared the index to his now-classic The Art of Computer Programming (TAOCP), he decided to put in the full name-including middle name, not just initials-of every author who appeared there. In the 1980s, he used an early prototype of $\mathrm{T}_{\mathrm{E}} \mathrm{X}$ to add Chinese and Japanese names in native script, and by the 1990s, he could include names in a wide range of alphabets and characters. "At last I did not have to rely entirely on transliteration when listing the name of the father of algorithms, Abu Ja'far Mohammed ibn Mūsā al- 


\section{COMMUNICATION}

Khowārizmī," wrote Knuth in a piece that appears in the "Recent News" section of his website. ${ }^{1}$ The name is written in Arabic as الخوارزمى موسى بن محمد.'.

Over the years, many people commented favorably to Knuth about this feature of TAOCP. "It has turned out to be a beautiful way to relish the fact that computer science is the result of thousands of individual contributions from people with a huge variety of cultural backgrounds," he wrote. To this day Knuth still works hard to include people's full names in his writing, often going to great lengths to uncover the names initials stand for. He even has a help page on his website where he offers US $\$ 2.56$ to those who can supply a missing name. "A lot of people have earned US\$2.56 in this way," he noted. His own MathSciNet author page includes his middle name (Ervin) as well as his Chinese name, 高德納.

Supporting the MathSciNet native script capability is of a piece with Knuth's appreciation for the beauty of names and their typographical representation. "My goal is to have the message [of the native script capability] get out to the people whose names up until now never appeared in an AMS journal because they were written in an exotic alphabet," Knuth said. "But also, I hope ordinary Americans and Germans and Poles and so on will update their MathSciNet author profiles as well." Updating is easy: Just visit your page in MathSciNet and click on the blue "Edit Author Profile" link.

The author profile page on MathSciNet provides an unostentatious way for authors to clearly identify themselves "among the billions of people on this planet," said Knuth. And having names appear in native script provides a new way to celebrate the human side of our discipline. "It shows how much we owe to all the different strands that make up mathematics."

\section{Photo Credits}

Photo of Donald Knuth lecturing courtesy of Dasha Slobozhanina. Sidebar photo of Donald Knuth at the keyboard courtesy of Peter Badge.

\section{Native Script Full Names of a Few Randomly}

\section{Chosen Mathematicians}

Ngô Bảo Châu: no bã:ự cəợ

Elon Lindenstrauss: לינדנשטראוסאילן

Heisuke Hironaka: 広中 平祐

Shiing Shen Chern: 陳省身

Srinivasa Iyengar Ramanujan:ஸீநீநிவாச இராமானுஜன்

Marina Evseevna Ratner: Мари́на Евсе́евна Ра́тнер

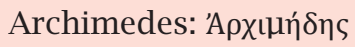

Karen K. Uhlenbeck: Karen Keskulla Uhlenbeck

V. F. R. Jones: Vaughan Frederick Randal Jones

Michael Atiyah: Michael Francis Atiyah (عطية مايكل) 
Math, Music, Mystery: A Brief Profile of Donald Knuth



Donald Knuth playing the organ in 2012. An accomplished musician and composer, he had a hard time deciding to major in physics rather than music when he was an undergraduate at Case Institute of Technology (now part of Case Western Reserve University).

Now 79 years of age, Donald Knuth is a legendary figure in the computer and mathematical sciences. He earned his $\mathrm{PhD}$ in mathematics in 1963 at Caltech, where his adviser was Marshall Hall. Knuth has made foundational contributions to several areas of computer science and also had an enormous impact through his multi-volume opus The Art of Computer Programming. His invention of the $\mathrm{T}_{\mathrm{E}} \mathrm{X}$ typesetting system revolutionized publication in the sciences and had a huge influence on communication among mathematicians. His long list of honors includes the 1974 Turing Award of the Association for Computing Machinery, the 1979 US National Medal of Science, and the 1996 Kyoto Prize of the Inamori Foundation.

Erudite and possessing broad knowledge, Knuth is nevertheless exceedingly modest and easy to talk to. He seems to say the first thing that pops into his mind, with a benevolent candor that's leavened by a quirky sense of humor. This unusual mix of qualities accounts for the success of his periodic lectures that go under the title "All Questions Answered," in which people show up and ask Knuth anything they want. ${ }^{2}$

Taking the interview for this article as a mini-instance of “All Questions Answered," this reporter asked about the question of P versus NP. "It's probably true that P equals NP, but we will never know why," Knuth answered. The question has two aspects, he explained. The first: Given a computational problem, does there exist a polynomial-time algorithm for its solution? And the second: Is that algorithm knowable-that is, can we actually write

${ }^{2}$ An edited transcript of one such lecture, held in Munich in 2001, appeared in the March 2002 issue of the Notices, www . ams . org/ notices/200203/fea-knuth.pdf. it down? "What I suspect is that there is some algorithm, it's out there, but it's so complicated that for practical purposes, it makes no difference because nobody will ever know what it is," he said. A suggestive example comes from the Robertson-Seymour theorem, which says that for any minor-closed family of graphs, there exists a polynomial-time algorithm to recognize whether a given graph belongs to the family. But "almost never do we know what the algorithm is."

Another totally different question: Why does he believe in God? He discussed this topic in six public lectures he gave at MIT in 1999 titled "Things a Computer Scientist Rarely Talks About." 3 "So many people have crazy opinions about religion, and that has given it a bad name," Knuth remarked. When he said in the lectures that he is a Christian, it felt "a little bit like coming out of the closet." It's different for Jews, he noted: in the audience for his lectures, there was little respect for someone being serious about religion, unless the person was Jewish.

The lectures didn't attempt to tell anyone what to think or believe. "I only said, these are important things and hard to contemplate, but you don't use standards of proof on them," he said. The question of the existence of God is "inherently unprovable." "I kind of like that," he went on. "I think my life would be incomplete if I knew everything, if there were no mystery. On the other hand, it would also be incomplete if it were all mystery. So I am willing to recognize the limits of what I know, but I'm also glad that mathematics gives me a chance to surround something and say, 'Yes, I do have some idea of truth."”

And music? It's a major passion for Knuth and figures in his unusual plan for celebrating his 80th birthday on January 10, 2018. Fulfilling a lifelong dream, Knuth has composed a 90-minute organ work called "Fantasia Apocalyptica," 4 based on the Book of Revelation. On his 80th birthday, one of the world's foremost organists, Jan Overduin, will perform the piece at the Studio Acusticum in Piteå, Sweden, which has a state-of-the-art organ. Projected onto screens in the concert hall will be several video tracks: one shows the Book of Revelation text in the original Greek with English translation; another displays the organist's score; and a third gives a comic-book style depiction of the action. The latter was created by Duane Bibby, who illustrated The $T_{E} X b o o k$. The premiere performance will cap a three-day international symposium called Knuth80, at which several dozen leading computer scientists, mathematicians, and typographers will speak.

"This event is really crazy, because who wants to go to northern Sweden in January?" Knuth remarked. "On the other hand, it's just crazy enough that it appeals to me. It's once in a lifetime. Sweden is actually a lot warmer than Chicago at that time of year. It's also got Northern Lights. And there won't be trouble getting hotels."

\footnotetext{
3 Annotated transcripts were published in 2001 under the same title. 4 www-cs-faculty.stanford.edu/ knuth/fant.htm1.
} 